\title{
ANALISIS SUMBER TSUNAMI UNTUK PERTIMBANGAN PERENCANAAN JALUR KABEL INACBT DI SELAT MAKASAR
}

\section{TSUNAMI SOURCE ANALYSIS FOR THE CONSIDERATION OF INACBT CABLE PLANNING IN MAKASSAR STRAIT}

\author{
Heru Sri Naryanto \\ Peneliti Ahli Utama pada Pusat Teknologi Reduksi Risiko Bencana (PTRRB), Kedeputian TPSA - \\ Badan Pengkajian dan Penerapan Teknologi (BPPT) \\ Gedung BPPT, JI. MH. Thamrin 8, Jakarta 10340; Gedung Geostech, Kompleks Puspiptek Serpong, \\ Tangerang Selatan \\ e-mail: heru.naryanto@bppt.go.id
}

\begin{abstract}
Part of North Penajam Paser Regency and part of Kutai Kartanegara Regency in East Kalimantan Province have officially been appointed as candidates for the new Indonesian Capital City. To provide a sense of security to the community in the prospective new capital city, a tsunami early warning system will be built. The Makassar Strait is located at the junction of three plates, namely the Indo-Australian Plate, the Eurasian Plate, and the Pacific Plate, resulting in complex tectonics and seismicity in the region. The potential for a tsunami in the Makassar Strait, either from earthquakes or submarine landslides, is high. The potential for a tsunami caused by the earthquake originates from the megathrust of North Sulawesi and many thrusts in the Makassar Strait. Meanwhile, submarine landslides are caused by unconsolidated rocks in steep morphology and submarine landslides due to the movement of faults due to earthquake shocks. The potential for submarine landslides is highly likely to occur due to landslides of the Mahakam Delta product sediment which empties into the Makassar Strait. In planning the InaCBT cable route, it will be endeavored to make the cable route pass through the Delta Mahakam sediment which has the potential for submarine landslides, cut through steep topography, consider bathymetry conditions, and adjust the marine cable master plan from the Ministry of Marine Affairs and Fisheries. The best alternative plan for the InaCBT cable line in the Makassar Strait by considering these various aspects is from Balikpapan City - Sarudu District (Pasangkayu Regency).
\end{abstract}

Keywords: tsunami source, earthquake, submarine landslide, tsunami cable line, Makassar Strait

\begin{abstract}
ABSTRAK
Sebagian wilayah Kabupaten Penajam Paser Utara dan sebagian Kabupaten Kutai Kartanegara di Provinsi Kalimantan Timur secara resmi telah ditunjuk menjadi calon lbu Kota Negara (IKN) Indonesia baru. Untuk memberi rasa aman kepada masyarakat di calon ibu kota baru tersebut nantinya akan dibangun sistem peringatan dini bencana tsunami. Selat Makassar terletak pada persimpangan tiga lempeng, yaitu Lempeng Indo-Australia, Lempeng Eurasia dan Lempeng Pasifik, menyebabkan tektonik dan kegempaan di kawasan tersebut sangat kompleks. Potensi tsunami di Selat Makassar baik berasal dari gempa maupun longsor bawah laut termasuk tinggi. Potensi tsunami yang disebabkan oleh gempa berasal dari megathrust Sulawesi Utara dan sesar-sesar naik yang berada di perairan Selat Makassar. Sementara longsor bawah laut diakibatkan oleh batuan tidak kompak pada morfologi curam serta longsor bawah laut akibat pergerakan sesar akibat goncangan gempa. Potensi longsor bawah laut sangat mungkin terjadi akibat longsornya endapan produk Delta Mahakam yang bermuara di Selat Makassar. Dalam merencanakan jalur kabel InaCBT diusahakan jalur kabel bisa melewati endapan Delta Mahakam yang berpotensi longsor bawah laut, memotong topografi terjal dengan memperhatikan kondisi batimetri, serta menyesuaikan master plan kabel laut dari Kementerian Kelautan dan Perikanan. Alternatif rencana jalur kabel InaCBT di Selat Makassar yang paling baik dengan mempertimbangkan
\end{abstract}


berbagai aspek tersebut adalah dari Kota Balikpapan - Kecamatan Sarudu (Kabupaten Pasangkayu).

Kata kunci: sumber tsunami, gempa, longsor bawah laut, jalur kabel tsunami, Selat Makassar

\section{PENDAHULUAN}

Gerakan tektonik di bagian timur Indonesia terbentuk akibat tumbukan lempeng-lempeng Indo-Australia, Pasifik, dan Eurasia. Tumbukan antar lempeng-lempeng tersebut telah membentuk zona subduksi. Pertemuan antar tiga lempeng di Indonesia bagian timur menghasilkan kondisi tektonik, geologi, struktur geologi, proses geologi yang sangat rumit. Gerakan penyusupan lempeng itu akan mengalami perlambatan akibat gesekan dari selubung bumi. Perlambatan gerak itu menyebabkan penumpukan energi di zona subduksi dan zona patahan, akibatnya pada zona-zona tersebut terjadi tekanan, tarikan, dan geseran yang berakibat terjadinya pelepasan energi berupa gempa (Natawidjaja, 2007; Naryanto, 2017; Naryanto, 2019).

Sulawesi terletak di Blok Sunda yang terletak di sebelah barat laut Lempeng IndoAustralia, sebelah timur Lempeng Eurasia, dan sebelah barat Lempeng Pasifik, evolusi tektoniknya sangat dipengaruhi oleh banyak mekanisme pergerakan lempeng-lempeng pengapitnya. Pulau Sulawesi terletak pada persimpangan tiga lempeng yang menyebabkan kawasan tersebut sangat kompleks, yang terekspresikan dengan banyaknya sesar (patahan) naik dan sesar geser. Sejarah tektonik Sulawesi berkaitan erat dengan perisitiwa tektonik regional di sekitar Sulawesi dan kegiatan tektonik lokal di berbagai bagian dari daerah Sulawesi, seperti pemekaran di Selat Makassar, rotasi dasar Laut Sulawesi, serta kegiatan-kegiatan tektonik di timur Sulawesi yang meliputi daerah Banggai Sula, Kendari, Muna dan Buton (Zakaria \& Sidarto, 2015; PGN, 2018).

Menurut Puspita et al. (2005), Selat Makassar terletak di dalam kawasan tektonik kompleks di tepi lempeng Eurasia di Indonesia. Cekungan Makassar Utara dibatasi di selatan oleh tepi utara Anjungan Paternoster, sering ditunjukkan sebagai sesar berarah barat laut tenggara, dengan alur dalam yang sempit menghubungkannya ke Cekungan Makassar Selatan. Di sebelah timur adalah Sesar PaluKoro, sesar geser kiri utama yang menghubungkan barat laut - tenggara dari daratan Sulawesi Barat ke Laut Sulawesi, dan di sebelah utara berupa Semenanjung
Mangkalihat yang merupakan sesar aktif berarah barat laut - tenggara.

Sekitar 71 kejadian tsunami di Indonesia atau hampir $9 \%$ dari jumlah tsunami di dunia, menempatkan Indonesia sebagai peringkat kedua yang paling sering dilanda bencana tersebut. Potensi kejadian yang tinggi tersebut karena letak geografis Indonesia yang berada pada pertemuan tiga (3) lempeng utama pembentuk kerak bumi (Pratomo \& Rudiarto, 2013). Kejadian tsunami besar di Indonesia dalam 3 tahun terakhir telah terjadi di Palu (September 2018) akibat pergerakan Sesar Palu-Koro yang kemungkinan menyebabkan longsor di Selat Palu, serta di Selat Sunda (Desember 2018) akibat longsor bawah laut dari aktivitas Gunung Anak Krakatau.

Potensi tsunami di Selat Makassar tinggi (Prasetya et al., 2001; Pratomo \& Rudiarto, 2013). Catatan sejarah menunjukkan bahwa sebagian besar disebabkan oleh gempa akibat pergerakan patahan dasar laut, kecuali peristiwa bencana tsunami Palu pada September 2018, yang kemungkinan memiliki komponen longsor (Jamelot et al., 2019). Menurut Brackenridge et al. (2019), potensi longsor bawah laut sangat mungkin terjadi akibat longsornya sedimen laut akibat endapan dari Delta Mahakam yang bermuara di Selat Makassar dari Provinsi Kalimatan Timur.

Peraturan Presiden (Perpres) No. 93 Tahun 2019 tentang Penguatan dan Pengembangan Sistem Informasi Gempabumi dan Peringatan Dini Tsunami sudah ditandatangani oleh Presiden, dan sejak itu permasalahan sistem peringatan dini tsunami (Tsunami Early Warning System/TEWS) sudah menjadi tanggung jawab bersama K/L terkait. K/L terlibat dalam kegiatan di bagian hulu, yaitu BMKG, BPPT, BIG, BNPB, dan BG, sementara BPPT ditugaskan menyelenggarakan deep sea level tsunami (buoy) dan Cable-Based Tsunameter (CBT). Kegiatan ini dilakukan melalui pola sinergitas antar $\mathrm{K} / \mathrm{L}$ yang didukung oleh BNPB melalui strategi 5 kekuatan bangsa yang terdiri dari: pemerintah, akademisi, dunia usaha, media, dan masyarakat untuk dapat mewujudkan Indonesia yang tangguh dan sejahtera (BPPT, 2019; Naryanto et al., 2020).

Provinsi Kalimantan Timur tepatnya di sebagian wilayah Kabupaten Penajam Paser Utara dan sebagian di Kabupaten Kutai Kartanegara, secara resmi telah ditunjuk 
menjadi calon Ibu Kota Negara (IKN) Indonesia baru. Untuk memberi rasa aman kepada masyarakat di calon ibu kota baru tersebut nantinya akan dibangun sistem peringatan dini bencana tsunami berbasis kabel Indonesia Cable-Based Tsunamener (InaCBT). Untuk mendapatkan gambaran penempatan rencana jalur kabel bawah laut, posisi lokasi sensor (OBU), maka perlu kajian komprehensif mengenai sumber bahaya tsunami baik itu berasal dari gempa tektonik yang bersumber di laut maupun longsor bawah laut di Selat Makassar.

\section{BAHAN DAN METODE}

\subsection{Lokasi dan Waktu Penelitian}

Lokasi penelitian dilakukan di Selat Makassar, antara Pulau Kalimantan dan Pulau Sulawesi. Penelitian dilakukan pada bulan Februari sampai Oktober 2020.

\subsection{Bahan}

Bahan yang diperlukan adalah peta tektonik dan kegempaan Indonesia dari Pusat Gempa Nasional, data gempa USGS, data tsunami dari BMKG dan USGS, peta batimetri DEMNAS, BATNAS, dan Peta Laut Indonesia (PLI).

\subsection{Metode Pengumpulan Data}

Metode penelitian di Selat Makassar dilaksanakan sebagai berikut:

- Koordinasi dengan instansi terkait,

- Pengumpulan data sekunder dan referensi terkait,

- Pengumpulan data primer langsung di lapangan,

- Pengolahan dan analisis data secara spasial, kualitatif, dan kuantitatif,

- Validasi data,

- Analisis tektonik, gempabumi, longsor bawah laut, dan tsunami
- Evaluasi data,

- Penyelesaian data,

Analisis jalur lintasan kabel dan posisi sensor (OBU).

\subsection{Metode Analisis Data}

Metodologi analisis risiko bencana gempabumi di Selat Makassar dilakukan melalui analisis teknis dengan menggunakan bantuan google earth, perangkat lunak extension spatial analyst pada software ArcGIS 10.6. Analisis data dengan melakukan pengolahan data kontur DEMNAS, BATNAS, PLI melalui software Global Mapper, dan analisis gempa search earthquake USGS.

\section{HASIL DAN PEMBAHASAN}

\subsection{Analisis Tektonik di Selat Makassar}

Menurut data Kementerian PU (2017), wilayah Indonesia memiliki 6 (enam) zona subduksi dengan 13 segmentasi megathrust dan 295 segmen sesar aktif. Tiga belas zona subduksi megathrust tersebut adalah AcehAndaman, Nias-Simelue, Batu, MentawaiSiberut, Mentawai-Pagai, Enggano, Selat Sunda, Jawa Tengah, Jawa Timur, Sumba, Sulawesi Utara, Philipina, dan Papua (Gambar 1). Salah satu megathrust yang paling dekat di sekitar Selat Makassar berada di utara Pulau Sulawesi, gempa besar yang bisa diikuti oleh tsunami akan bisa berdampak terhadap tsunami di sekitar perairan Selat Makassar. Pembagian segmen megathrust tersebut menunjukkan besaran potensi gempa yang mungkin terjadi menurut segmennya. Dari informasi keberadaan megathrust tersebut bisa diketahui ancaman gempa yang berpotensi menimbulkan tsunami. Sesar aktif yang terbentuk di Pulau Sulawesi sangat banyak (Gambar 2).

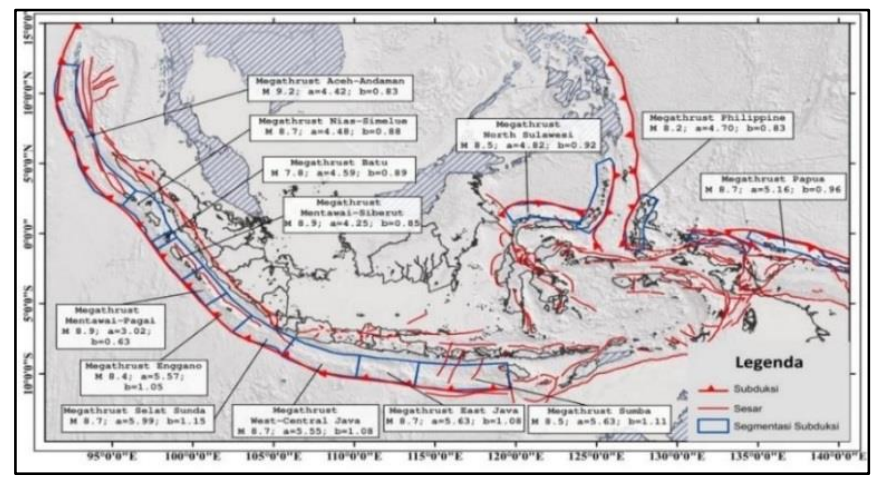

Gambar 1. Peta Tektonik, Megathrust dan Patahan Aktif yang Tersebar di Wilayah Indonesia (Kementerian PU, 2017) 


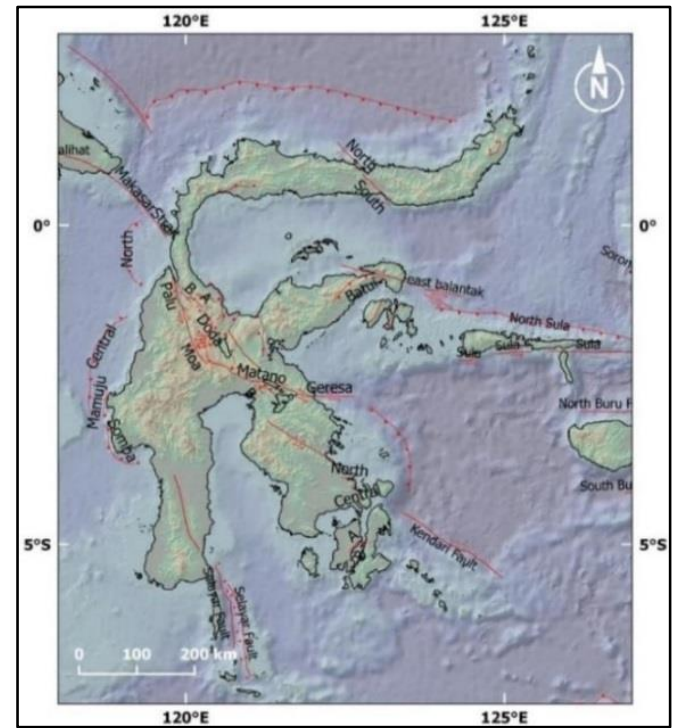

Gambar 2. Peta Sesar Aktif di Pulau Sulawesi yang Terangkum dalam Peta Gempa Nasional 2017 (Kementerian PU, 2017)

Menurut Netherwood \& Wight (1992), struktur utama di Cekungan Tarakan, Kalimantan bagian utara adalah lipatan dan sesar yang umumnya berarah barat lauttenggara dan timur laut-barat daya. Cekungan Tarakan terdapat 3 buah sesar geser kiri (sinistral strike slip fault), sedangkan di cekungan Kutai banyak didominasi oleh sesarsesar turun dan mendatar berarah utara dan barat laut.

Naryanto et al. (2020), menjelaskan kejadian gempa yang terjadi di Kalimantan tidak sesering pulau-pulau lainnya di Indonesia. Beberapa sejarah gempa pernah terjadi di kawasan tersebut. Gempa pada tanggal 20 Desember 2015 tercatat kejadian gempa dengan kekuatan M 6,1 SR, dengan kedalaman $38 \mathrm{~km}$ telah mengguncang wilayah Tarakan hingga terasa dengan skala intensitas MMI VVI. Peristiwa tersebut mengindikasikan bahwa Pulau Kalimantan tidak sepenuhnya aman dari ancaman gempa bumi. Zona sesar yang berada di Kalimantan diantaranya yaitu Sesar Tarakan, Sesar Mangkalihat, dan Sesar Meratus, yang berpotensi menimbulkan gempa dengan kekuatan M 7 SR.

Kondisi geologi Selat Makassar dipengaruhi oleh mekanisme ekstensional lempenglempeng. Hal ini ditunjukkan dari bukti-bukti di Sulawesi Barat ditemukan bukti lipatan dan sesar naik yang berarah ke barat sedangkan di Kalimantan Timur menunjukkan bukti lipatan dan sesar naik ke arah timur. Penampang seismik di bagian timur Selat Makassar menunjukkan sedimen muda tersesarkan naik bersudut tinggi dan perlipatan ke arah barat. Amplitudo lipatan semakin kecil ke arah barat, bagian tengah tidak terdeformasi. Bukti tersebut menunjukkan pengaruh gaya kompresi dimulai dari bagian tepi Selat Makassar sehingga bagian tengah selat belum terdeformasi (Bachri, 2012; Bernando et al., 2017).

Menurut Bernando et al. (2017), struktur yang berkembang di bagian selatan Selat Makassar tepatnya di Sabuk Patahan Naik Sulawesi Barat (West Sulawesi Fault Thrust Belt (WSFTB) merupakan fault propagation fold. Struktur ini juga tercermin dengan jelas pada peta topografi dasar laut. Mekanismenya konsisten pada setiap garis seismik arah barat timur yang menunjukkan kemiringan sesar dorong yang relatif tegak lurus di sepanjang struktur geologi di bagian selatan (Gambar 3). Intensitas perambatan lipatan menurun ke selatan. Sedimen di atas permukaan decollement tersesarkan oleh sesar transform berarah barat laut-tenggara. Berdasarkan model Riddle Shear, maka bentuk struktur yang berkembang di Selat Makassar lebih condong menganan. Elipsoid model menunjukkan sesar naik dengan arah utara-selatan, lipatan pada arah utara-selatan, dan sesar geser kanan dengan arah barat laut-tenggara (Gambar 4).

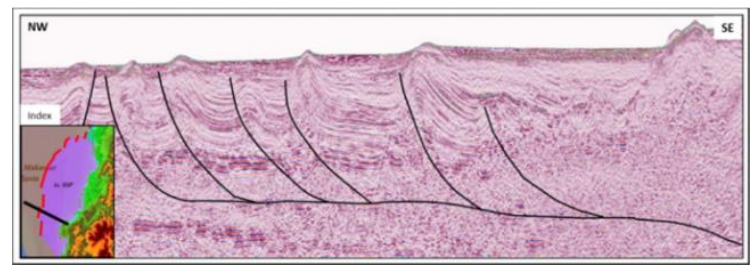

Gambar 3. Penampang Melintang dari Data Seismik yang Menunjukkan Fault Propagation Fold di sebelah Barat Provinsi Sulawesi Barat (Bernando et al., 2017)

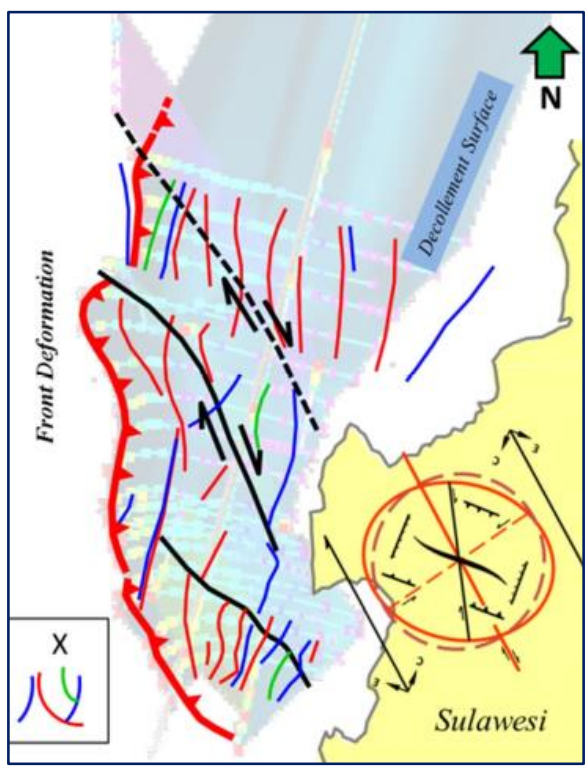

Gambar 4. Supra Fault Menunjukkan Sesar Mendatar Arah Kanan Hasil dari Model Riddle Shear (Bernando et al., 2017) 
Berdasarkan data seismik di Selat Makassar, didapatkan adanya sesar normal yang berorientasi timur laut - barat daya. Sesar ini merupakan sesar tumbuh. Hubungan antara data seismik tersebut dengan geologi daratan diperkirakan berupa perselingan batupasir dan batulempung yang termasuk dalam Formasi Pasangkayu berumur Pliosen Akhir hingga Plistosen. Dijumpainya diapir yang muncul menunjukkan adanya suatu zona lemah atau rekahan yang diterobos lapisan batuan di atasnya yang berumur hingga Kuarter. Pembentukan diapir di Selat Makassar menunjukkan adanya aktivitas tektonik yang masih berlangsung sampai saat ini (Hanafi \& Arifin, 2010).

\subsection{Analisis Gempa Penyebab Tsunami}

Dalam melakukan kajian gempa, pertimbangan besaran gelombang gempa tidak terlepas dari proses atenuasi gelombang dari pusat gempa ke lokasi dan proses amplifikasi dari batuan dasar ke batuan di permukaan. Kedua hal tersebut yang akan mempengaruhi respon spektral percepatan untuk desain bangunan di permukaan tanah. Adapun proses atenuasi ini dikelompokkan menjadi 3 , yaitu shallow crustal earthquake di tektonik aktif, shallow crustal di wilayah stabil/kontinen dan yang ketiga di wilayah subduksi (Abrahamson and Silva, 1997; Wisyanto \& Naryanto, 2020).

Pulau Sulawesi memiliki tatanan sesar rumit yang terdiri atas sesar yang masih aktif bergerak dan tidak lagi bergerak. Daryono (2016) mendeskripsikan 20 sesar secara sistematis dan sumber-sumber gempa yang pernah terjadi di kawasan tersebut (Gambar 5). Badan Geologi (2012) telah membuat peta Kawasan Rawan Bencana (KRB) Gempabumi, yang menunjukkan pantai barat (dari Sulawesi Barat sampai Palu) serta Sulawesi Utara mempunyai bahaya gempabumi tinggi. Patahan naik (thrust) yang berada di Selat Makassar dan utara Sulawesi juga berpotensi sebagai sumber gempa yang bisa menyebabkan terjadinya tsunami (Gambar 6).

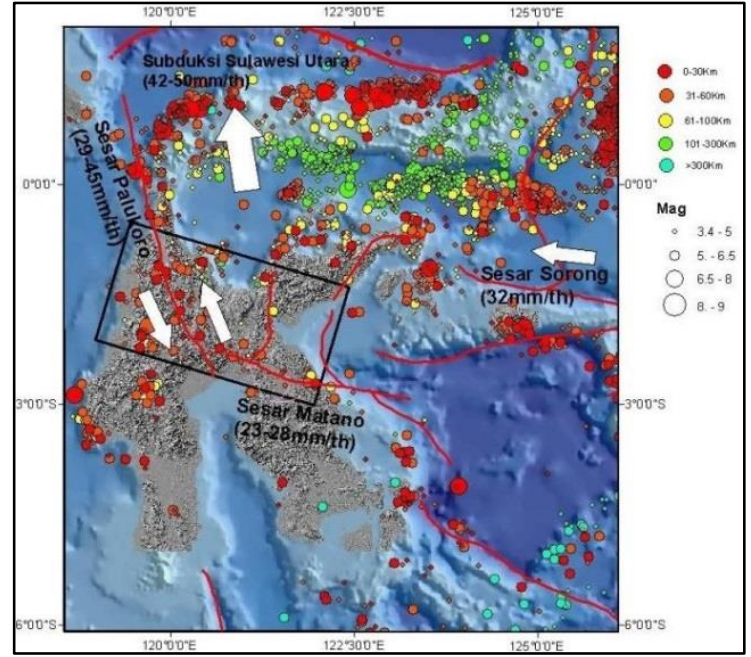

Gambar 5. Struktur Geologi Regional dan Kegempaan di Pulau Sulawesi (Daryono, 2016).

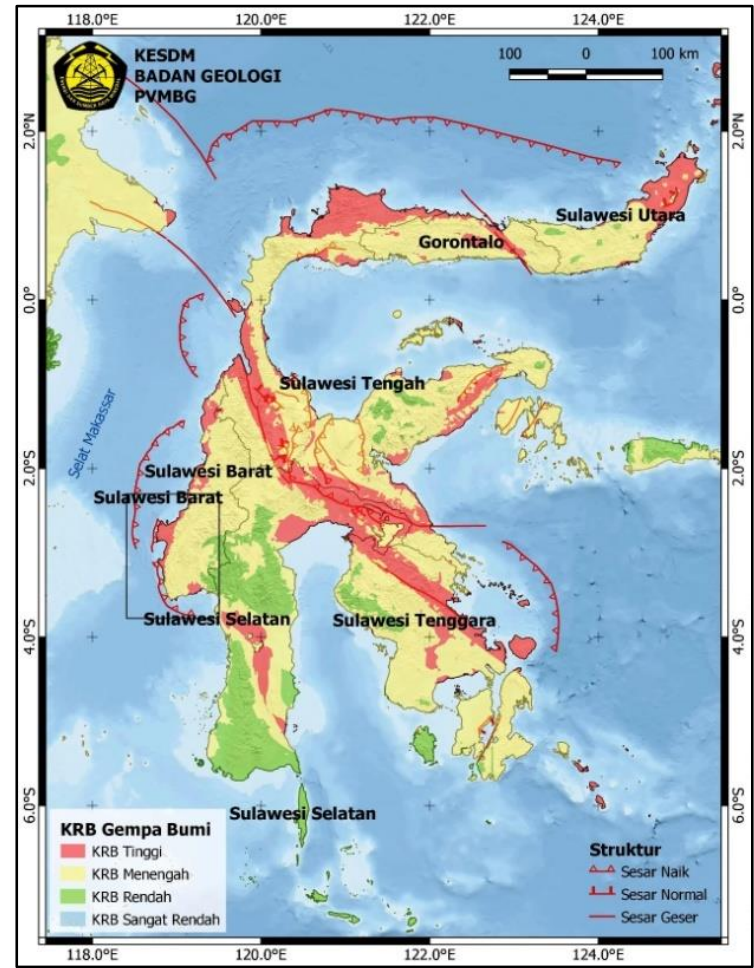

Gambar 6. Peta Kawasan Rawan Bencana

Gempabumi di Pulau Sulawesi (Badan Geologi, 2012).

Sebagian besar gempa di Indonesia biasanya dapat digolongkan ke dalam gempa tektonik yang berasosiasi dengan perbatasan lempeng. Gempa yang berasosiasi dengan lempeng yang menunjam di bawah lempeng lain, disebut sebagai gempa subduksi. Gempa tersebut rata-rata mempunyai kedalaman antara 30 sampai $700 \mathrm{~km}$. Engdahl (2006) telah melakukan plotting terhadap gempa-gempa dengan skala lebih dari 5 SR yang terjadi dalam kurun waktu 1964 sampai 2006 secara 
regional di wilayah Indonesia bagian timur. Selain titik-titik gempa, Engdahl juga mencantumkan kedalaman pusat gempanya. Dari hasil plotting yang dilakukannya terlihat bahwa pusat gempa di Sulawesi banyak terjadi pada zona patahan Palu-Koro, megathrust Sulawesi Utara, patahan aktif di Sulawesi Barat dan Sulawesi bagian timur.

Sejarah gempa yang berada di Selat Makassar penting untuk diketahui agar bisa dilakukan analisis kegempaan di kawasan tersebut. Untuk itu dilakukan pengambilan data gempa yang berasal dari United States Geological Survey (USGS). Data gempa yang diambil adalah gempa dengan magnitude antara $6-9$ SR dengan pertimbangan magnitude tersebut bisa memicu terjadinya tsunami, dan data gempa yang diambil adalah dari tahun 1900 sampai bulan Maret 2021.

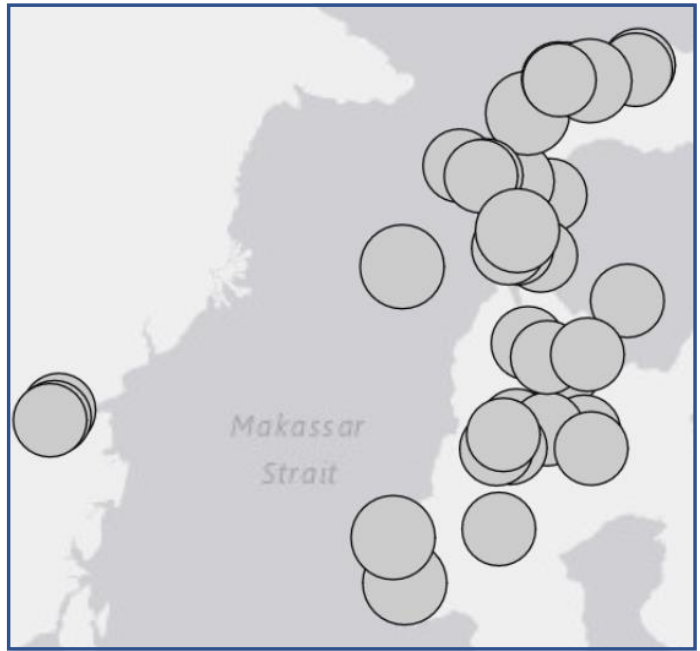

Gambar 7. Analisis Sebaran Kejadian Gempa

Lebih dari 6 - 9 SR dari Tahun 1900 Sampai

Maret 2021 di Selat Makassar dengan

Parameter Magnitude Gempa Menggunakan

Data Gempa USGS

Wilayah Selat Makassar yang akan menjadi penempatan lokasi kabel laut InaCBT berada di zona megathrust Sulawesi Utara dengan potensi magnitude gempa sampai dengan 8,5 $\mathrm{SR}$ dengan nilai koefisien $\mathrm{b}$ value yang rendah artinya masih menyimpan tegangan yang tinggi dan berpotensi terjadi gempa besar. Sedangkan wilayah lain disekitarnya yaitu Tarakan memiliki potensi M 7,4 SR dan Selat Makassar mempunyai potensi M 7,1 - 7,3 SR.

Kongko (2020) telah melakukan simulasi model tsunami dengan asumsi skenario sumber gempa besar berasal dari megathrust Sulawesi Utara. Berdasarkan pemodelan tersebut, tinggi gelombang tsunami yang akan terjadi diperkirakan mencapai $1-3 \mathrm{~m}$. Elevasi tertinggi di Balikpapan sebesar 0,85 m dengan rentang $0,25 \mathrm{~m}-0,85 \mathrm{~m}$.
Sementara perkiraan waktu tiba tsunami di pantai calon IKN paling cepat sekitar 1,6 jam dari sumbernya dengan rentang waktu 1,6 jam - 2 jam.

Peristiwa gempa yang terjadi di lokasi sekitar Selat Makassar didominasi oleh sesar oblique reverse atau sesar oblique naik, yang merupakan sesar kombinasi dari strike-slip dan dip-slip (Robinson, 1987). Jenis pergerakan yang terjadi sesuai dengan 3 sesar utama yang aktif di Kalimantan yaitu sesar mendatar dan sesar naik. Peristiwa gempabumi yang diikuti dengan tsunami terjadi pada tahun 1938 dan 1996 dengan kekuatan gempa sebesar M 7,7 SR di Kalimantan Timur sampai dengan Gorontalo dan M 7,9 SR di Minahasa.

Gempa pada tahun 1938 dengan skala intensitas MMI VIII - IX dan bersama dengan aftershock telah mengakibatkan lebih dari 900 rumah rusak parah. Sedangkan pada tahun 1996 terjadi gempa bumi akibat sesar oblique naik yang diikuti tsunami lokal di Minahasa dengan ketinggian run-up 1 s.d 5 meter dengan korban meninggal 5-10 orang (BMKG, 2019). Kedua gempa bumi yang menyebabkan tsunami diperkirakan memiliki mekanisme bola fokal yang sama dan tergolong dalam gempa dangkal yang berpotensi menimbulkan gelombang tsunami.

Pada tahun 2018 terjadi peristiwa gempa berkekuatan M 6,1 SR dengan mekanisme pergerakan sesar mendatar yang diikuti dengan gelombang tsunami. Sedangkan di bagian selatan Palu terjadi gempa M 7,5 SR. Peristiwa tersebut diikuti 40 kejadian aftershock dengan magnitude 4,4 SR. Panjang rupture di Palu diperkirakan lebih dari $150 \mathrm{~km}$. Berdasarkan peristiwa-peristiwa gempa yang terjadi, maka persentasi kemungkinan terjadinya gempa yang menyebabkan tsunami di Selat Makassar adalah $20 \%$.

\subsection{Analisis Longsor Bawah Laut Penyebab Tsunami}

Data perairan di bagian barat Selat Makassar banyak ditemukan material endapan yang dipengaruhi oleh proses transportasi sedimen dari darat terutama yang berada di dekat Delta Mahakam. Endapan sedimen bawah laut di bagian barat Selat Makassar dekat Pulau Kalimantan lebih tebal dibandingkan dengan bagian timur Selat Makassar.

Menurut Kusnida \& Arifin (2008), di daerah Delta Mahakam diidentifikasi ada empat (4) sekuen sedimentasi yang dipisahkan oleh bidang tidak selaras. Lapisan Delta Mahakam terbentuk oleh produk gelombang laut dan gelombang pasang surut yang menyusun suatu 
susunan sistem deltaik pantai berumur Miosen sampai Resen. Progradasi Sungai Mahakam membentuk endapan sedimen karbonat paparan berulang dan endapan delta silisiklastik, endapan lumpur sangat mendominasi material di dataran Delta
Mahakam. Dari data penampang seismik, terlihat adanya diapir yang menerobos sekuen A dengan kedalaman diapir tumbuh $40 \mathrm{~m}$ dari dasar laut dan menerobos $15 \mathrm{~m}$ ke dalam dasar laut (Gambar 8).

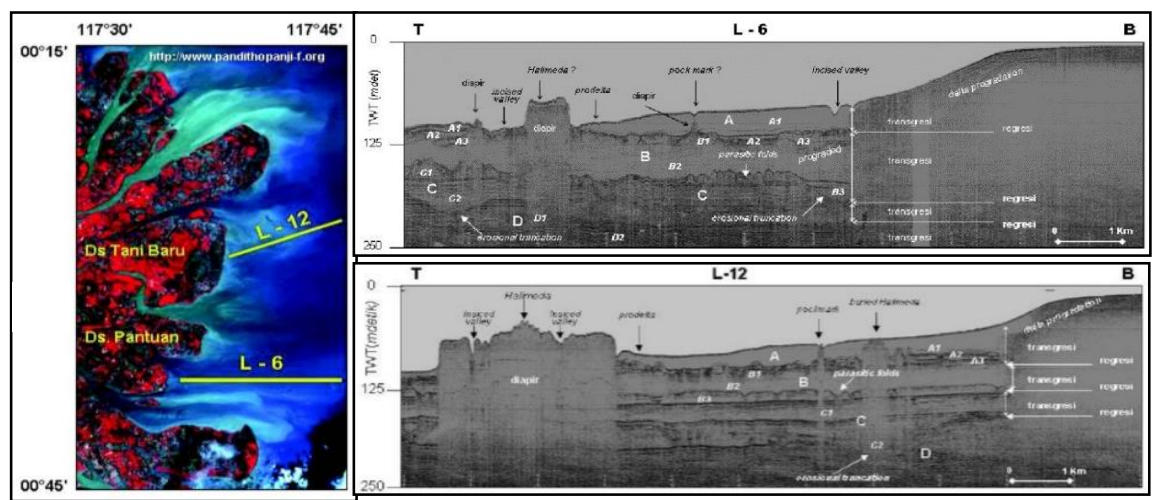

Gambar 8. Proses Pengendapan Sekuen Delta dari Penampang Seismik Delta Mahakam (Kusnida \& Arifin, 2008)

Ada banyak faktor di Selat Makassar rentan terhadap tsunami yang dipicu oleh longsor bawah laut, yang dipicu oleh lereng yang sangat terjal pada dasar laut, pertumbuhan karbonat, patahan, serta influx sedimen dari Delta Mahakam. Selat Makassar menjadi saluran utama Indonesian Through Flow (ITF), yang merupakan jalur penting dalam menghubungkan Samudera Pasifik dan Samudera Hindia. Endapan massa tanah terbesar teridentifikasi berada di tiga lokasi yaitu di bagian dasar lereng kontinen di bagian barat daya cekungan utara Selat Makassar, selatan Delta Mahakam. Endapan massa tanah diperkirakan berasal dari longsoran bawah laut translasional. Belum ada rekaman yang menjelaskan mengenai kejadian tsunami akibat longsoran di Selat Makassar. Hal ini menimbulkan dua kemungkinan antara transportasi massa sedimen bawah laut tidak berpengaruh terhadap tsunami atau tsunami yang dihasilkan oleh longsoran bawah laut Selat Makassar ini memiliki frekuensi yang lebih kecil dibandingkan tsunami yang dihasilkan oleh sesar (Brackenridge et al., 2020; Amos, 2020).

Bahan-bahan yang diangkut ke dalam cekungan dari Delta Mahakam didistribusikan kembali di lereng atas ke selatan delta, yang mengakibatkan peningkatan laju sedimentasi di wilayah ini. Dalam kombinasi dengan ukuran butiran halus, penguburan yang cepat meningkatkan retensi cairan dan pembentukan tekanan berlebih, meningkatkan kemungkinan kegagalan lereng. Sifat halus dan berlumpur membuatnya cenderung memiliki kekuatan geser yang rendah, dan morfologi ke atas yang cembung menghasilkan gradien yang tinggi secara lokal di lereng atas benua. Semua faktor ini membuat simpanan ini secara inheren tidak stabil dan rentan gagal.

Berdasarkan analisis peta dari google earth menunjukkan adanya kemiringan lereng yang berbeda di perairan Selat Makassar bagian barat. Tingkat kelerengan yang tinggi serta, produk material yang berasal dari endapan Delta Mahakam yang berumur relatif muda. Batuan belum terkonsolidasi dengan sempurna, sehingga labil dan mudah goyah untuk menyebabkan terjadinya longsor bawah laut. Kekuatan gelombang tsunami yang diakibatkan oleh longsoran bawah laut adalah volume longsoran, kedalaman air dari titik awal jatuhan, serta percepatan longsoran. Apabila longsoran bawah laut Selat Makassar ini terjadi, dapat menimbulkan tsunami yang diperkirakan akan berdampak terhadap lokasi calon IKN. Morfologi yang relatif curam di barat Sulawesi Barat juga berpotensi terhadap longsor bawah laut. Banyaknya patahan aktif yang terbentuk di kawasan tersebut juga menunjang terhadap potensi longsor bawah laut. 


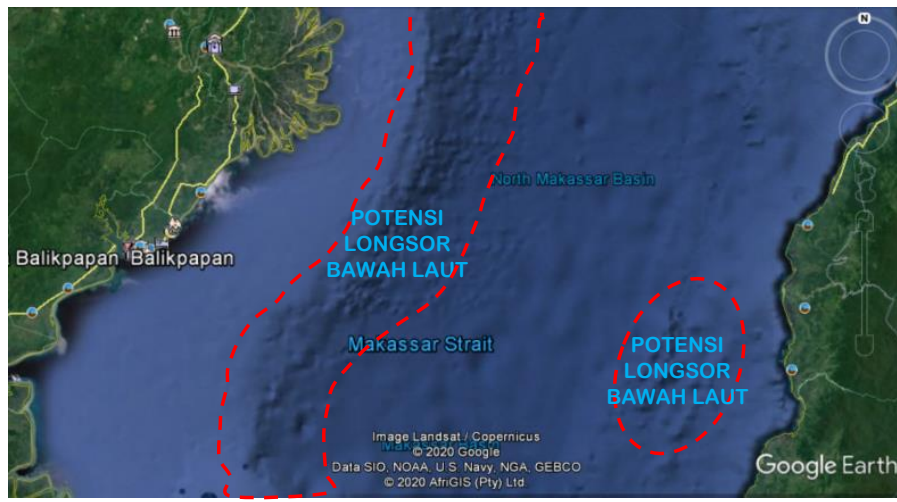

Gambar 9. Zona Potensi Longsor Bawah Laut yang Tinggi pada Kemiringan yang Cukup Tinggi dan Produk dari Endapan Delta Mahakam di Selat Makassar Berdasarkan Analisis Peta dari Google Earth

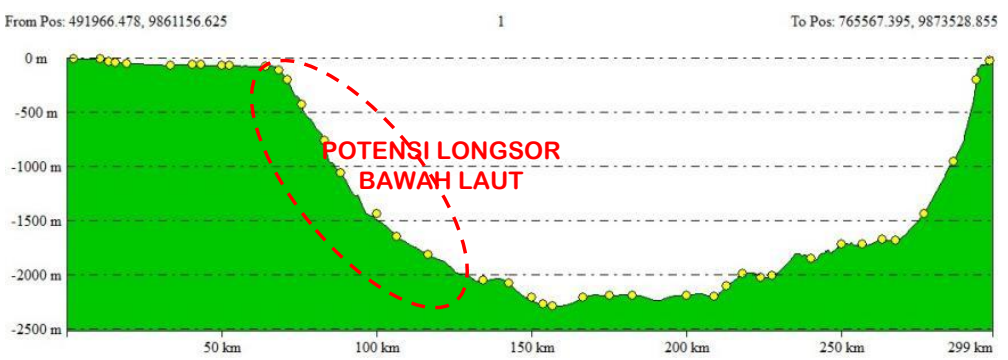

Gambar 10. Penampang Batimetri Bawah Laut dari Kota Balikpapan ke Pasangkayu yang Menunjukkan Potensi Longsor Bawah Laut Produk Material Delta Mahakam pada Topografi Terjal di Perairan Sisi Pulau Kalimantan

Berdasarkan analisis data di Selat Makassar, potensi pemasangan infrastruktur peringatan dini tsunami sistem kabel di lokasi calon Ibu Kota Negara (IKN) baru cukup tinggi. Jika dilihat dari sisi tektonik, potensi tsunami di Selat Makassar termasuk tinggi, terutama berasal dari megathrust di bagian utara Sulawesi Utara, sesar-sesar yang banyak terdapat di perairan Selat Makassar, Sesar Palu-Koro, dan lainnya. Kaitannya dengan longsor bawah laut di Selat Makassar, dibutuhkan pemodelan dan analisis lebih rinci mengenai skenario kejadian tsunami akibat longsoran bawah laut tersebut. Brackenridge et al. (2019) juga telah mengidentifikasi lokasi potensi longsor di Selat makassar tersebut (Gambar 11).

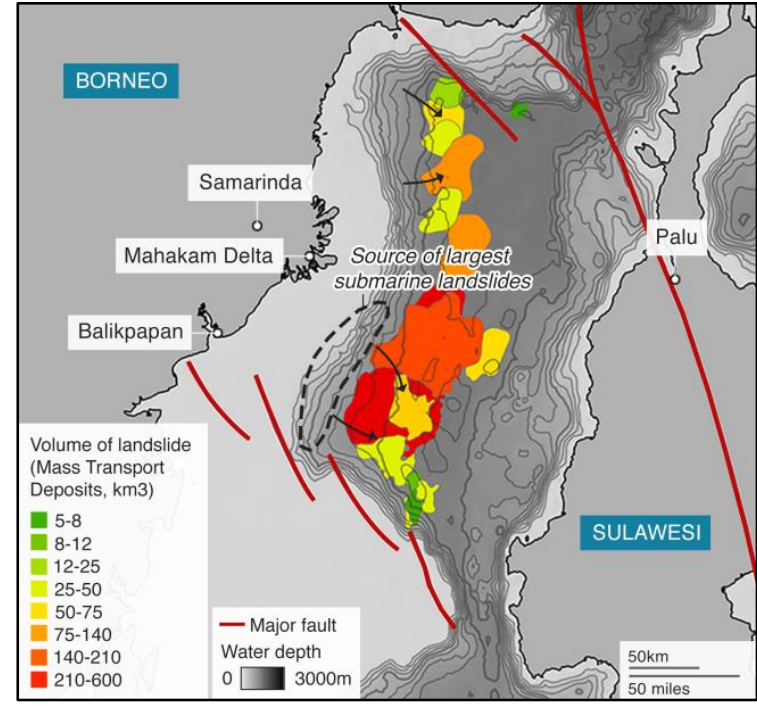

Gambar 11. Potensi Longsor Bawah Laut di Selat Makassar (Brackenridge et al., (2019)

\subsection{Diskusi}

Potensi tsunami yang diakibatkan oleh gempa, biasanya bersumber dari sesar naik yang terletak di laut. Potensi tsunami di Selat Makassar tersebut berasal dari Megathrust Sulawesi Utara, sesar naik Selat Makassar Utara (North Sulawesi Strait), sesar naik Selat Makassar Tengah (Central Sulawesi Strait), sesar naik Mamuju dan sesar naik Somba di barat Provinsi Sulawesi Barat. Potensi gempa selain sesar naik (sesar geser atau sesar 
normal) juga memungkinkan bisa menyebabkan gelombang tsunami apabila diikuti dengan longsor bawah laut. Sesar-sesar tersebut antara lain adalah sesar Palu-Koro, sesar Tarakan, sesar Mangkalihat, sesar di barat Sulawesi Barat, dan sebagainya.

Dalam rangka untuk melindungi kawasan calon IKN, apabila terjadi tsunami yang bersumber dari gempa megathrust Sulawesi Utara akan mempunyai waktu yang cukup untuk memberi peringatan dini ke masyarakat. Apabila sumber gempa berasal dari sesarsesar di barat Provinsi Sulawesi, waktu yang dibutuhkan untuk penyampaian peringatan dini ke Provinsi Sulawesi Barat terlalu pendek, sementara ada waktu cukup untuk penyampaian peringatan dini ke lokasi IKN.

Potensi tsunami yang diakibatkan oleh longsor bawah laut sangat tinggi berasal dari sedimentasi yang berasal dari Delta Mahakam. Material produk endapan delta tersebut belum terlalu kompak, membentuk topografi terjadi di dasar laut, sehingga potensi longsor bawah laut tinggi. Longsor bawah laut tersebut akan sangat mungkin menyebabkan gelombang tsunami yang bisa menjadi bencana. Potensi tsunami akibat longsor bawah laut tersebut terdapat di sepanjang pantai Provinsi Kalimantan Timur. Potensi longsor bawah laut sepanjang pantai Provinsi Kalimantan Timur sampai selatan karena endapan sedimen terbawa arus. Selain itu morfologi dasar laut relatif curam juga terdapat di bagian barat Mamuju (Provinsi Sulawesi Barat). Banyak sesar-sesar di kawasan tersebut, sumber gempa pada daerah yang berdekatan akan sangat mungkin menyebabkan longsor bawah laut yang bisa menyebakan tsunami.

Dalam merencanakan jalur kabel InaCBT, untuk mendapatkan data rekaman dari OBU maka kabel diusahakan memotong dengan endapan Delta Mahakam serta memotong topografi terjal. Alternatif jalur paling baik adalah relatif berarah barat - timur. Jalur kabel dari sisi Pulau Kalimantan bisa dimulai dengan landing point dari arah Sangata, Bontang, Samarinda, Tanjung Santan, Muara Jawa, Balikpapan, dan Penajam. Untuk menangkap sumber tsunami yang berasal dari longsor bawah laut tidak bisa dari Sangata, Bontang, dan Penajam karena berada di luar zona endapan delta yang berpotensi longsor.

Pertimbangan rencana jalur kabel InaCBT harus menyesuaikan dengan master plan kabel laut dari Kementerian Kelautan dan Perikanan (KKP). Berdasarkan master plan kabel laut KKP, dari sisi Pulau Kalimantan dimulai dari Sangata dan Balikpapan, sementara dari sisi Pulau Sulawesi berada di Donggala dan direncanakan juga ke arah Sarudu (Kabupaten Pasangkayu).

Pemilihan jalur kabel InaCBT dengan landing point di Balikpapan adalah pilihan paling tepat, karena sudah sesuai dengan master plan kabel laut KKP, melewati lokasi potensi longsor bawah laut dari endapan Delta Mahakam, selain itu infrastuktur sudah sangat lengkap kaitannya dengan sumber energi listrik, sistem komunikasi untuk penempatan landing station (power house dan tower komunikasi).

Sementara untuk pemilihan landing point di sisi Pulau Sulawesi ada beberapa alternatif, yaitu di Palu, Donggala, Pasangkayu, Sarudu, Mamuju, dan Majene. Master plan kabel laut KKP yang ada Pulau Sulawesi adalah di Donggala dan Sarudu (Kabupaten Pasangkayu). Pemilihan landing point di Sarudu (Kabupaten Pasangkayu) adalah alternatif yang paling memungkinkan, karena jarak relatif paling dekat dan lurus dari Kota Balikpapan dibandingkan dengan Donggala. Sehingga pilihan paling memungkinkan adalah rencana jalur InaCBT di Selat Makassar adalah Kota Balikpapan - Kecamatan Sarudu (Kabupaten Pasangkayu). Panjang lintasan dalam jarak lurus dari peta google earth adalah $270 \mathrm{~km}$, dan akan sangat mungkin lebih panjang lagi apabila penempatan jalur kabel mengikuti kontur batimetri yang sesuai.

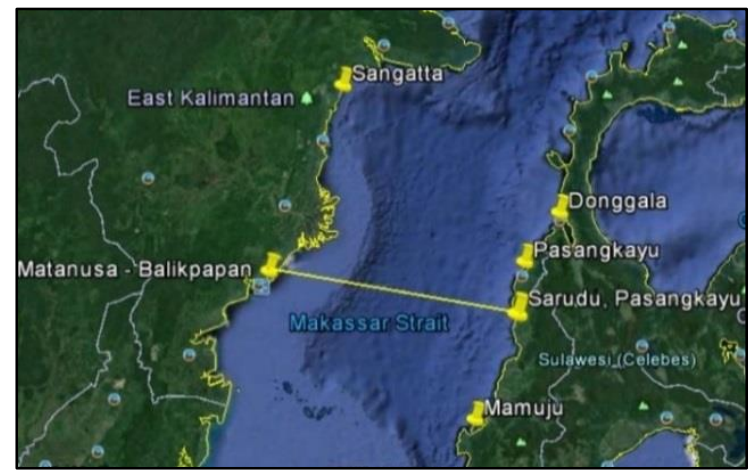

Gambar 12. Alternatif Jalur Kabel InaCBT dari Kota Balikpapan ke Kecamatan Sarudu, Kabupaten Pasangkayu dari Peta Google Earth

\section{KESIMPULAN}

Sulawesi terletak di Blok Sunda yang terletak diantara Lempeng Indo-Australia, Lempeng Eurasia, dan Lempeng Pasifik, sehingga evolusi tektoniknya sangat kompleks, yang menyebabkan kawasan tersebut terekspresikan dengan banyaknya sesar naik, sesar geser, kondisi tektonik, geologi, struktur geologi, dan proses geologi yang sangat kompleks.

Potensi tsunami yang diakibatkan oleh gempa, biasanya bersumber dari sesar naik 
yang terletak di laut, yaitu berasal dari megathrust Sulawesi Utara, sesar naik Selat Makassar Utara (North Sulawesi Strait), sesar naik Selat Makassar Tengah (Central Sulawesi Strait), sesar naik Mamuju, dan sesar naik Somba di barat Provinsi Sulawesi Barat. Potensi gempa selain sesar naik juga memungkinkan bisa menyebabkan gelombang tsunami apabila diikuti dengan longsor bawah laut. Sesar-sesar tersebut antara lain adalah Sesar Palu-Koro, Sesar Tarakan, Sesar Mangkalihat, sesar di barat Sulawesi Barat, dan sebagainya.

Potensi tsunami yang diakibatkan oleh longsor bawah laut sangat tinggi berasal dari sedimentasi yang berasal dari Delta Mahakam. Material produk endapan delta tersebut belum terlalu kompak, membentuk batimetri curam di dasar laut. Selain itu juga ada potensi longsor bawah laut di barat Mamuju pada batimetri curam di daerah zona patahan aktif.

Rencana jalur kabel InaCBT di Selat Makassar paling baik adalah Kota Balikpapan Kecamatan Sarudu (Kabupaten Pasangkayu). Pemilihan lokasi landing station dan landing point di Kota Balikpapan dan Pasangkayu dengan pertimbangan mempunyai fasilitas yang memadai dalam hal energi listrik, komunikasi, ketersediaan lahan, kemudahan akses, infrastruktur, dan sebagainya.

\section{PERSANTUNAN}

Penulis mengucapkan banyak terima kasih kepada: bapak M. llyas (Direktur PTRRB), rekan-rekan seperjuangan bapak Wisyanto, bapak Mulyo Harris Pradono, mbak Dian Nuraini Melati, mbak Puspa Khaerani, mbak Syakira Trisnafiah, dan mbak Atikah Zahra yang telah banyak membantu dalam penyelesaian artikel ini.

\section{DAFTAR PUSTAKA}

Abrahamson, N. A. and W.J. Silva. 1997. Empirical Response Spectral Attenuation Relations for Shallow Crustal Earthquakes. Seismological Research Letters (1997) 68 (1): 94-127. https://doi.org/10.1785/gssrl.68. 1.94.

Amos, J. 2020. Tsunami Risk Identified Near Future Indonesian Capital. [terhubung berkala].https://www.bbc.com/news/scienceenvironment-52388352 [17 Januari 2021].

Bachri, S. 2012. Fase Kompresi di Selat Makassar Berdasarkan Data Geologi Daratan, Seismik Laut Dan Citra Satelit. Jurnal Sumber Daya Geologi, 22(3): 13744.
Badan Geologi. 2012. Peta Kawasan Rawan Bencana (KRB) Gempa Bumi Pulau Selawesi.

Bernando N, I. Heseklel. Wahyudi, and R.M.I. Argakoesoemah, 2017. Structural Style of The Southern Province of West Sulawesi Fault. Proceedings Indonesian Petroleum Association, Forty-First Annual Convention \&

BMKG. 2019. Katalog Gempabumi Signifikan dan Merusak 1821 - 2018, 280 halaman.

BPPT. 2019. Grand Design InaTEWS BPPT $2019-2024$.

Brackenridge, R, U. Nicholson, B. Sapiie, D. Stow \& D. R. Tappin. 2019. Indonesian Throughflow as a preconditioning mechanism for submarine landslides in the Makassar Strait. Geological Society, London, Special Publications, DOI: https://doi.org/10.1144/SP500-2019-171.

Daryono, M. 2016. Paleoseismologi Tropis Indonesia (Dengan Studi Kasus di Sesar Sumatera, Sesar Palu-Koro-Matano dan Sesar Lembang). Disertasi, Program Studi Doktor Sain Kebumian, ITB.

Engdahl, E.R. 2006. Application of an Improved Algorith to High Precision Relocation of ISC Test Events: Physics of the Earth and Planetary Interiors. v. 158: 14-18.

Hanafi, M. dan L. Arifin. 2010. Struktur Geologi di Perairan Pasang Kayu, Sulawesi Barat. Jurnal Geologi Kelautan, 8(3): 119-25.

Jamelot, A., A. Gailler, P. Heinrich, A. Vallage, and J. Champenois. 2019. Tsunami simulations of the sulawesi Mw 7.5 event: Comparison of seismic sources issued from a tsunami warning context versus postevent finite source, Pure and Applied Geophysics, vol. 176, no. 8, pp. 3351-3376. https://doi.org/10.1007/s00024-019-02274-5.

Kementerian PU. 2017. Peta Sumber dan Bahaya Gempa Indonesa Tahun 2017.

Kongko, W. 2020, Simulasi Tsunami Megathrust Sulut M 8.5 untuk Kajian Lokasi Calon IKN (Untuk Optimasi Lokasi OBU), Bahan Diskusi Ina TEWS, BPPT, 24 Maret 2020.

Kusnida, D. dan L. Arifin. 2008. Karakteristik Akustik dan Fenomena Geologi Endapan Sedimen Kuarter Delta Mahakam Kalimantan Timur. Jurnal Geologi Kelautan, 6(3): 167-173.

Naryanto, H.S. 2017. Potensi Gempa dan Tsunami di Kabupaten Banggai Laut, Provinsi Sulawesi Tengah. Jurnal Sains dan Teknologi Mitigasi Bencana. 12(2): 46-60.

Naryanto, H.S. 2019. Analisis Bahaya, Kerentanan Dan Risiko Bencana Tsunami Di Provinsi Papua Barat, Jurnal Alami, 3(1): 10-20. 
Naryanto, H.S., Wisyanto, I.G. Tejakusuma, D.N. Melati, M.H. Pradono, B. Marwanta, F. Prawiradisastra, Q. Zahro, R.P. Umbara, A. Zahra, P. Khaerani, S. Trisnafiah, D.B. Putra, \& A.F. Shomim. 2020. Desktop Study Indonesia Cable Based Tsunameter (InaCBT) Selat Makassar, Laporan, PTRRBBPPT, Jakarta.

Natawidjaja, D.H. 2007. Tektonik Setting Indonesia dan Pemodelan Gempa dan Tsunami, Pelatihan Pemodelan Tsunami Run-up, RISTEK. 20 Agustus, 2007.

Netherwood, R., and A. Wight. 1992. Structurally-Controlled, Linear Reefs in a Pliocene Delta-Front Setting, Tarakan Basin, Northeast Kalimantan. Carbonate Rocks and Reservoirs of Indonesia: A Core Workshop, $37 \mathrm{pp}$.

Peraturan Presiden (Perpres) RI No. 93 Tahun 2019 tentang Penguatan dan Pengembangan Sistem Informasi Gempa Bumi dan Peringatan Dini Tsunami.

Prasetya, G.S., W.P. De Lange, and T.R. Healy. 2001. The Makassar Strait Tsunamigenic Region, Indonesia. Natural Hazards, 24: 295-307, https://doi.org/10. 1023/A:1012297413280.

Pratomo, R.A. and I. Rudiarto. 2013. Permodelan Tsunami dan ImplikasinyaTerhadap Mitigasi Bencana di Kota Palu, Jurnal Pembangunan Wilayah dan Kota, 9(2):174-182.

Pusat Gempa Nasional (PGN). 2018. Kajian Gempa Palu, Sulawei Tengah 28 September 2018, 300 halaman.

Puspita, S.D., R. Hall, and C.F. Elders. 2005. Structural Styles of the Offshore West Sulawesi Fold Belt, North Makassar Straits, Indonesia. Proceedings, Indonesian Petroleum Association, Thirtieth Annual Convention \& Exhibition, August 2005, Jakarta, 519-542, IPA05-G-110.

Robinson, K., 1987. Location Map of Major Tertiary Sedimentary Provinces and Structural Elements of the Circum-Borneo Region, Southeast Asia. U.S. Geological Survey World Energy Resources Program International. Open-File Report 87-495-F, https://doi.org/10.3133/ofr87495F

USGS, NEIC. 2021. Seismic Hazard of Makassar Strait, Map Prepare by United State of Geology Survey, URL http://earthquake.usgs.gov/research/hazmap /product_data/

Wisyanto and Naryanto, H.S. 2020. Analisis Tingkat Ancaman Gempabumi di Kabupaten Nganjuk, JSTMB, 15(1): 52-62

Zakaria, Z. and Sidarto. 2015. Tectonic Activities in the Sulawesi and Surrounding
Area Since Mesozoics to Recent as the Impacts of Tectonic Activity of the Surrounding Main Plate Tectonics, JGSM. 16(3): $115-127$. 